\title{
FAKTOR YANG MEMPENGARUHI PRESTASI BELAJAR PESERTA DIDIK
}

\author{
Yuzarion \\ STKIP PGRI Sumatera Barat, Jalan Gunung Pangilun 1 Padang \\ Email: yuzarionzubir11@gmail.com
}

\begin{abstract}
The results showed that the structural model has a decent (GFI $=0.930$, AGFI $=$ $0.908>0.90 ; \mathrm{CFI}=0.990, \mathrm{TLI}=0.988>0.95$, and $\mathrm{RMSEA}=0.029<0.08)$ and obtain the support of empirical data $(\mathrm{X} 2=169.029$ and $\mathrm{p}=0.068>0.05)$. Factors parents attitudes toward children, the attitude of teachers toward students, and self-regulated learning influence on student achievement. Parents' attitudes toward children, the attitude of teachers towards students direct effect on self-regulated learning and indirect effect on student achievement through selfregulated learning. These findings support the social cognitive theory.
\end{abstract}

Keywords: parents' attitudes, teachers' attitudes, self-regulated learning, learning achievement

\begin{abstract}
Abstrak: Hasil penelitian menujukkan bahwa model struktural layak (GFI =0,930, AGFI = $0,908>0,90 ;$ CFI $=0,990$, TLI $=0,988>0,95 ;$ dan RMSEA $=0,029<0,08)$ dan memperoleh dukungan data empiris $(\mathrm{X} 2=169,029$ dan $\mathrm{p}=0,068>0,05)$. Faktor sikap orangtua terhadap anak, sikap guru terhadap peserta didik, dan self-regulated learning berpengaruh terhadap prestasi belajar peserta didik. Sikap orangtua terhadap anak, sikap guru terhadap peserta didik, berpengaruh langsung terhadap self-regulated learning dan berpengaruh tidak langsung terhadap prestasi belajar peserta didik melalui self-regulated learning. Temuan ini mendukung teori kognitif sosial.
\end{abstract}

Kata kunci: sikap orangtua, sikap guru, self-regulated learning, prestasi belajar

Berbagai laporan mengungkapkan bahwa prestasi belajar (academic achievement) peserta didik Indonesia kurang optimal. Laporan-laporan tersebut antara lain oleh The International Association for the Evaluation of Educational Achievement (IEA) Tahun 2011. IEA merupakan salah satu lembaga Internasional independen, melakukan penelitian dan studi dalam skala besar mengukur perbandingan prestasi dan aspek-aspek lain pendidikan di 64 negara di dunia sebagai peserta. Dari hasil pengukuran kemampuan bidang IPA dan matematika Internasional, pelajar SMP Indonesia berada pada urutan 38 dari 39 negara yang disurvei (IEA, 2011), sedangkan hasil pengukuran Trends in International Mathematics and Science Study (TIMSS) Tahun 2011, kemampuan matematika pelajar SMP Indonesia juga berada pada urutan 34 dari 38 negara, sedangkan kemampuan pelajar Indonesia pada bidang IPA berada di urutan ke 32 dari 38 negara yang disurvei (TIMSS, 2011).
Kualitas pendidikan Indonesia seperti yang dilaporkan oleh The International Association for the Evaluation of Educational Achievement (IEA) dan Trends in International Mathematics and Science Study (TIMSS), perlu dicermati dan ditindaklanjuti. Berdasarkan pralapangan diketahui bahwa SMA Negeri 1 Lawang Kabupaten Malang: skor rata-rata nilai Ujian Nasional (UN) lima mata pelajaran perolehan nilai dengan rentang skor 8.6 sampai dengan 10 hanya diperoleh oleh 26 dari 412 peserta didik yang ikut dan dinyatkan lulus UN 2012. Hal ini berarti bahwa hanya 6.28\% lulus dengan prestasi belajar yang baik, sementara 274 peserta didik (66.52\%) berada pada posisi sedang dan 112 peserta didik (27.20\%) berada pada posisi rendah. Lebih lanjut, penelusuran literatur, cukup banyak penelitian yang mencoba mengungkapkan kasus menyontek. Penelitian Rittman (1996); Bogle (2000); dan Turrens, dkk., (2002) mencoba 
sebagai alat instrumenasinya. Penelitian Thorpe, dkk., (1999) perilaku menyontek terjadi karena nilai pelajar rendah karena kemampuannya memang rendah, ia memiliki hasrat untuk mendapatkan nilai belajar yang lebih tinggi.

Selanjutnya penelitian Battist (1999) gradasi moral juga berkorelasi dengan perilaku menyontek serta penelitian Richards, dkk., (2006) kekuatan berpikir berhubungan dengan perilaku menyontek. Permasalahan lain, seperti sistem evaluasi, ujian semester maupun ujian nasional, terlalu menekankan pada jawaban pilihan ganda (multiple choice) tanpa memperhatikan prosesnya, keberhasilan peserta didik sering dinilai hanya berdasarkan pada sejauh mana peserta didik mampu mereproduksi bahan pengetahuan yang diberikan, dan mencari satu jawaban yang paling benar terhadap suatu permasalahan, sistem evaluasi ini ini tidak melihat suatu masalah dari berbagai sudut pandang dan aspek-aspek utama, seperti kemampuan memberikan macam-macam kemungkinan jawaban secara lancar, luwes, unik dan terinci kurang dirangsang (Daruma, 1997). Permasalahan pembelajaran dengan menggunakan metode ceramah menjadikan guru sebagai sumber utama pengetahuan serta memposisikan pelajar sebagai penerima pasif informasi. Belen (2003) mengatakan bahwa ciri sekolah yang kurikulumnya berbasis pada materi, selain sumber belajarnya hanya mengandalkan guru dan buku pelajaran, juga pendekatan belajarnya bersifat satu arah.

Permasalahan lain ialah aktivitas belajar lebih menekankan pada materi yang diberikan guru berdasar soal-soal UN yang pernah ada dan pembahasan soal-soal UN-nya, bukan pada silabus yang telah dirancang. Kegitan belajar mengajar sampai sekarang di sekolah tidak banyak berubah, pola pengajaran teacher centered masih mendominasi kegiatan pembelajaran, guru masih cenderung menggunakan pertanyaan yang membutuhkan jawaban singkat dan bersifat hafalan. Kegiatan pembelajaran tidak memberikan peluang kepada pelajar untuk mengembangkan diri, sebab guru masih memandang pelajar sebagai objek, kenyataannya guru masih mengajar, apa yang harus dipikirkan bukan mengajarkan bagaimana cara berpikir (Ismayati, 2009). Di sisi lain orangtua mensikapi UN sebagai proyek prestisius dan fenomenal Departemen Pendidikan dan Kebudayaan ini sesuatu yang luar biasa. Jauh sebelum pelaksanaan UN orangtua stress lebih dahulu dari anaknya dan tidak sedikit orangtua memproteksi anak untuk menghadapi UN, sehingga pola pengasuhan otoriter cenderung meningkat sebelum hari pelaksanaan UN.

Untuk menghadapi UN orangtua harus bersikap memberikan dukungan psikologis pada pelajar sehingga mereka semakin siap mental untuk menghadapinya. Berbagai tekanan psikologis muncul dari orangtua, guru, kepala sekolah, dinas pendidikan, wali kota, bupati, dan bahkan gubernur yang mengharuskan peserta didik lulus dalam UN Hal ini membuat peserta didik semakin stress saat hendak UN Persoalan pelik seperti yang dipaparkan di atas merupan virus perusak prestasi belajar yang amat memprihatinkan. Dari sisi pelajar hasil yang diperoleh tidak menggambarkan perolehan nilai yang sesungguhnya. Sangat sering diterima informasi yang dibaca dari media masa maupun informasi dari media elektronik pelajar yang punya prestasi baik, lalu tidak lulus UN, tidak jarang juga terdengar peserta didik selama ini berprestasi biasa bahkan cenderung rendah, prestasi UN mereka baik. Dari sudut pandang self-regulated learning (SRL) terlihat bahwa self-regulated learning (SRL) sebahagian peserta didik rendah. Laporan atas temuan-temuan tersebut mengindikasikan kurang baiknya kualitas pendidikan di Indonesia sekaligus mencerminkan belum berhasilnya pemerintah dan masyarakat Indonesia untuk meningkatkan kualitas pendidikan.

Upaya-upaya yang selama ini yang dilakukan pemerintah untuk meningkatkan kualitas pendidikan khususnya prestasi belajar peserta didik. Nampak tidak didasari oleh analisis yang mendalam dan komprehensif tentang berbagai faktor yang mempengaruhi prestasi belajar itu. Upaya-upaya yang selama ini dilakukan pemerintah untuk meningkatkan prestasi belajar peserta didik lebih menekankan pada penanganan faktor lingkungan (faktor eksternal) seperti meningkatkan kesejahteraan guru serta mengembangkan sarana dan prasaran pendidikan. Faktor-faktor perilaku (faktor internal) seperti motivasi belajar peserta didik, kebiasaan belajar dan self-regulated learning (SRL) belum mendapatkan perhatian yang serius. Faktor-faktor yang mempengaruhi prestasi belajar dalam teori kognitif sosial (social cognitive theory) 
menurut Bandura dibangun dari dua faktor utama, yaitu: (1) faktor perilaku (faktor internal) peserta didik; dan (2) faktor lingkungan (faktor eksternal) peserta didik dalam belajar (Brown, 1999; Hergenhahn \& Olson, 2009).

Faktor internal peserta didik dalam penelitian ini adalah self-regulated learning (SRL), sedangkan faktor eksternal sikap orangtua terhadap anak dan sikap guru terhadap terhadap peserta didik, dalam banyak jurnal tiga faktor tersebut merupakan faktor yang banyak mempengaruhi prestasi belajar. Permasalahan mendasar yang dikaji penelitian ini berhubungan dengan: (1) prestasi belajar peserta didik; (2) sikap orangtua terhadap anak; (3) sikap guru terhadap peserta didik; dan (4) self-regulated learning (SRL). Empat permasalahan yang paling mendasar tersebut diangkat dalam penelitian ini sebagai variabel laten eksogenus dan variabel laten endogenus. Sikap orangtua terhadap anak dan sikap guru terhadap peserta didik merupakan variabel laten eksogenus terhadap self-regulated learning (SRL) dan prestasi belajar peserta didik. Self-regulated learning (SRL) merupakan variabel laten eksogenus terhadap prestasi belajar peserta didik, sekaligus berfungsi sebagai variabel laten endogenus terhadap sikap orangtua terhadap anak dan sikap guru terhadap peserta didik. Prestasi belajar peserta didik sebagai variabel laten endogenus dalam penelitian ini.

\section{METODE}

Penelitian ini merupakan penelitian noneksperimen atau penelitian ex post facto, yaitu suatu penelitian yang ditujukan untuk menguji pengaruh suatu variabel terhap variabel lain yang telah terjadi secara natural. Dalam penelitian ini digunakan desain penelitian korelasional, karena penelitian ini bertujuan menguji pengaruh suatu variabel terhadap variabel lain yang telah terjadi secara natural pada satu kelompok subyek penelitian. Populasi dalam penelitian ini adalah seluruh peserta didik kelas XI SMA Negeri se Kota Malang. Populasi dalam dalam penelitian ini berjumlah 3.139 orang siswa yang tersebar pada sepuluh SMA Negeri di Kota Malang. Sampel dalam penelitian ini adalah 285 orang siswa. Teknik pengambilan sampel yang akan digunakan adalah teknik random sampling inependen.
Pengukuran variabel laten eksogenus dalam penelitian ini menggunakan instrumen dalam bentuk skala. Skala yang digunakan dalam penelitian ini adalah: (1) skala sikap orangtua terhadap anak; (2) skala sikap guru terhadap peserta didik; (3) skala self-regulated learning (SRL); dan (4) prestasi belajar peserta didik sebagai variabel laten endogenus diambil dari pencatatan dokumen prestasi belajar matematika, bahasa Indonesia, dan bahasa Inggris peserta didik. Data dalam penelitian ini dianalisis dengan menggunakan teknik analisis Structural Equation Modeling (SEM) digunakan untuk menguji pengaruh antar variabel model teoritik yang telah dirancang dengan tujuan apakah hubungan kausal antara sikap orangtua terhadap anak, sikap guru terhadap peserta didik, selfregulated learning (SRL) terhadap prestasi belajar peserta didik mendapatkan dukungan empiris dalam penelitian ini.

Pengujian model dengan menggunakan AMOS akan menghasilkan indek kesesuaian model dengan menilai goodness of fit indek sama, lebih besar dari cut of value/nilai kritisnya. Model yang fit (layak/baik) adalah model yang memiliki nilai goodness of fit indek sama atau lebih besar dari cut of value/nilai kritisnya. Jika model belum layak, menurut Santoso (2014) peneliti dapat melakukan modifikasi pada sebuah model agar beberapa alat uji dapat lebih bagus hasilnya, seperti penurunan angka chi-square, peningkatan angka GFI, dan sebagainya. Menurut Atmoko (2008) modifikasi dapat dilakukan berkali-kali sampai ditemukan sebuah model yang terbaik atau paling layak. Modifikasi model harus tetap berpijak dengan dukungan teori yang kuat (Hair, dkk., 1998); Hair, dkk., 2006; Hair, dkk., 2010; Atmoko, 2008; Ghozali, 2013; Satoso, 2014).

Lebih lanjut Santoso (2014) menjelaskan analisis SEM dengan AMOS tersedia dua alternatif rekomendasi modifikasi model SEM, alternatif pertama rekomendasi dari modification indices pada output covariances: (group number 1-default model), dan alternatif kedua output regression weights: (group number 1-default model). Analisis SEM pada penelitian ini menggunakan alternatif pertama, penggunaan alternatif pertama ini berpijak pada model triadic reciprocality dari teori kognitif sosial Bandura (Bandura, 1986; Brown, 1999; Hergenhahn \& Olson, 2009). 


\section{HASIL}

Penelitian ini untuk mendapatkan model yang fit/layak dilakukan 4 kali modifikasi. Modifikasi model SEM dilakukan dengan tahapan: (1) memilih alternatif modifikasi indek covariances pada output AMOS; (2) mencermati dan memilih sumbangan penurunan angka chi-square terbesar pada kolom MI (modification indices); (3) melakukan proses modifikasi dengan menghubungkan garis dengan dua anak panah berdasarkan saran sumbangan penurunan angka chi-square terbesar pada kolom MI (Modification Indices); dan (4) melakukan proses pengujian ulang. Hasil pengujian model SEM atau pengujian model persamaan struktural, pengujian model pengukuran (measurement model) dan 4 kali modifikasi model diuraikan sebagai berikut. Berdasarkan Gambar 1 hasil uji model persamaan struktural awal disajikan pada Tabel 1.

\section{Model Persamaan Struktural Awal}

Berdasarkan Tabel 1 menilai kelayakan model persamaan struktural awal diperoleh informasi tujuh kriteria penilaian memenuhi syarat, kriteria penilaian tersebut adalah: (1) derajat bebas/ df $=147$ berarti baik; (2) Chisquare/df $=1,339$ berarti baik; (3) GFI $=0,920$ berarti baik; (4) AGFI $=0,896$ berarti marginal; (5) CFI $=0,980$ berarti baik; (6) TLI = 0,977 berarti baik; dan (7) RMSEA $=0,039$ berarti baik. Namun, dua kriteria penilaian yang lain belum memenuhi syarat dan bernilai kurang baik. Maka dapat disimpulkan model persamaan struktural awal belum layak. Karena model persamaan struktural awal belum

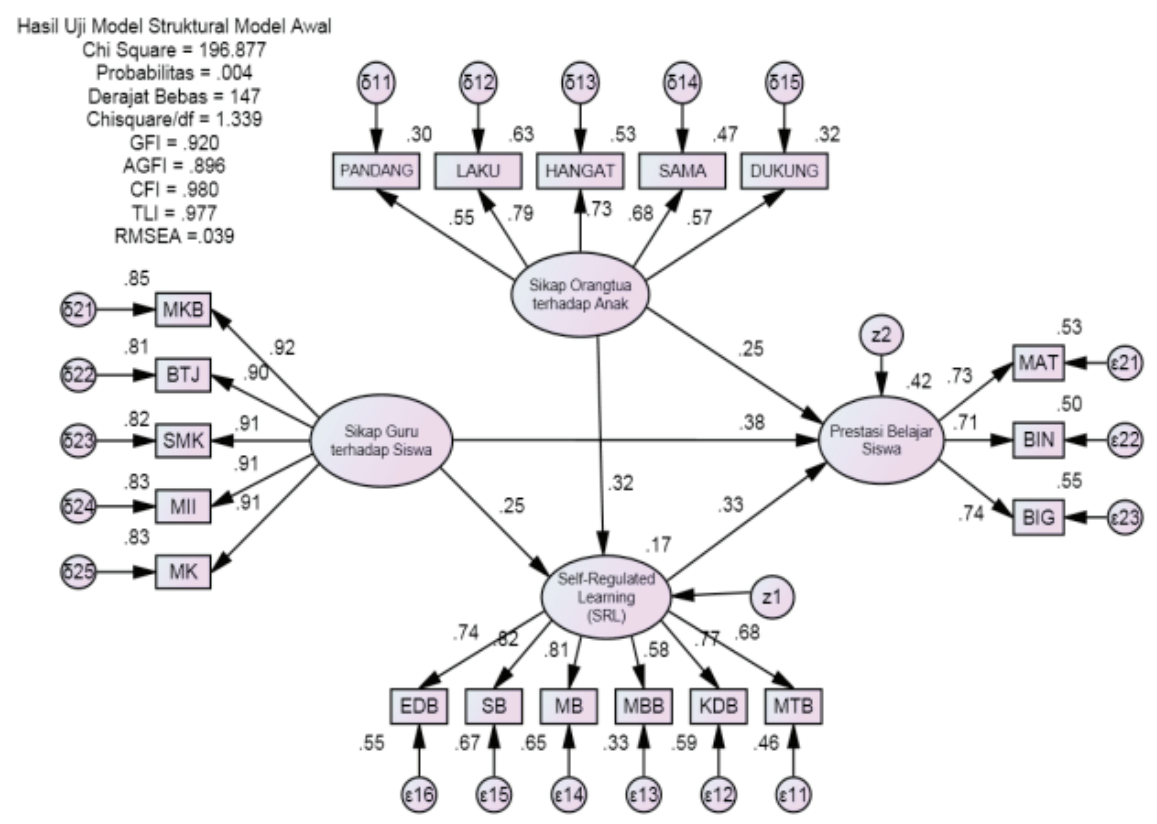

\section{Gambar 1 Hasil Uji Model Persamaan Struktural Awal}

Tabel 1 Hasil Uji Model Persamaan Struktural Awal

\begin{tabular}{|c|c|c|c|c|}
\hline No & Kriteria Penilaian & Hasil & Nilai Kritis & Keterangan \\
\hline 1 & Chi Square $=\backslash \mathrm{cmin}$ & 196.877 & Kecil (mendekati df) & Kurang Baik \\
\hline 2 & Probabilitas $=\backslash p$ & .004 & $\geq 0.05$ & Kurang Baik \\
\hline 3 & Derajat Bebas $=\backslash \mathrm{df}$ & 147 & positif & Baik \\
\hline 4 & Chisquare $/ \mathrm{df}=\backslash \mathrm{cmindf}$ & 1.339 & $\leq 2.00$ & Baik \\
\hline 5 & $\mathrm{GFI}=\backslash \mathrm{gfi}$ & .920 & $\geq 0.90$ & Baik \\
\hline 6 & $\mathrm{AGFI}=\backslash \mathrm{agfi}$ & .896 & $\geq 0.90$ & Marginal \\
\hline 7 & $\mathrm{CFI}=\backslash \mathrm{cfi}$ & .980 & $\geq 0.95$ & Baik \\
\hline 8 & $\mathrm{TLI}=\backslash \mathrm{tli}$ & .977 & $\geq 0.95$ & Baik \\
\hline 9 & RMSEA $=$ rmsea & .039 & $\overline{<0.08}$ & Baik \\
\hline
\end{tabular}


layak, peneliti melakukan modifikasi. Modifikasi dilakukan berdasarkan rekomendasi dari output AMOS modification indices covariances. Modifikasi model dilakukan bertahap, sampai 4 kali modifikasi. Hasil modifikasi 4 diperoleh hasil pada Gambar 2.

Setelah uji kelayakan model persamaan struktural terpenuhi seperti Gambar 2, langkah selanjut melakukan pengujian hipotesis, diuraikan sebagai berikut. Pengujian hipotesis mayor, dilakukan setelah peneliti memperoleh model yang terbaik/layak. Dengan berpedoman pada nilai chi-square $\left(\mathrm{X}^{2}\right)$ dan probabilitas, diperoleh nilai chi-square $\left(\mathrm{X}^{2}\right)=169,029$ dengan $p=0,068$ ( -probability level $>0,05)$. Perolehan nilai chisquare $\left(\mathrm{X}^{2}\right)$ dan probabilitas menjelaskan tidak berbeda secara signifikan antara matrik kovarian sampel (data empiris) dengan matrik kovarian estimasi (model yang dibangun). Hasil pengujian hipotesis mayor dapat disimpulkan $\mathrm{H}_{\mathrm{o}}$ diterima, berarti model persamaan stuktural yang telah dibangun mendapat dukungan empiris.

Pengujian hipotesis minor dilakukan dengan memeriksa hasil koefisien regresi antar konstruk (variabel) dalam model persamaan struktural yang dibangun. Merujuk pada Atmoko (2008) tingkat pengaruh antar konstruk (variabel) diuji dengan hipotesis nol bahwa koefisien regresi antar konstruk (variabel) adalah tidak berbeda dengan nol atau koefisien $\mathrm{R}=0$ dalam analisis regresi, dan nilai critical ratio $(\mathrm{CR})$ hasi analisis $>2$ sebagai nilai kritis tabel. Tingkat signifikansi pengaruh ditentukan oleh nilai $p$-value $<0,05$. Hasil pengujian hipotesis minor dapat dilihat pada Tabel 2. Lebih lanjut, disajikan ringkasan signifikansi hasil pengujian hipotesis, dapat dilihat pada Tabel 3.

Tabel 3 keseluruhan model menunjukkan angka signifikan, interpretasi signifikansi hasil pengujian hipotesis diuraikan sebagai berikut:

Sikap orangtua terhadap anak berpengaruh positif dan signifikan terhadap prestasi belajar peserta didik. Maksudnya semakin baik sikap orangtua terhadap anak, maka akan semakin baik juga prestasi belajar peserta didik. 1) sikap guru terhadap peserta didik berpengaruh positif dan signifikan terhadap prestasi belajar peserta didik. Maksudnya semakin baik sikap guru terhadap peserta didik, maka akan semakin baik juga prestasi belajar peserta didik. 2) sikap orangtua terhadap anak berpengaruh positif dan signifikan terhadap self-regulated learning (SRL) peserta didik. Maksudnya sikap orangtua terhadap anak yang baik, maka akan diikuti oleh self-regulated learning (SRL) peserta didik yang baik. 3) sikap guru terhadap peserta didik berpengaruh positif dan signifikan terhadap self-regulated learning (SRL) peserta didik. Maksudnya sikap guru terhadap peserta didik yang baik, maka akan diikuti oleh self-regulated learning (SRL) peserta didik yang baik.

4) self-regulated learning (SRL) berpengaruh positif dan signifikan terhadap prestasi belajar peserta didik. Maksudnya semakin baik selfregulated learning (SRL) peserta didik, maka akan semakin baik juga prestasi belajar peserta didik. 5) sikap orangtua terhadap anak berpengaruh positif dan signifikan terhadap prestasi belajar peserta didik melalui self-regulated learning (SRL) peserta didik. Maksudnya semakin baik sikap orangtua terhadap anak, maka akan semakin baik juga prestasi belajar peserta didik melalui selfregulated learning (SRL) peserta didik yang baik. 6) sikap guru terhadap peserta didik berpengaruh positif dan signifikan terhadap prestasi belajar peserta didik melalui self-regulated learning (SRL) peserta didik. Maksudnya semakin baik sikap guru terhadap peserta didik, maka akan semakin baik juga prestasi belajar peserta didik melalui selfregulated learning (SRL) peserta didik yang baik juga.

Hasil penelitian ini membuktikan bahwa hubungan kausal sikap orangtua terhadap anak, sikap guru terhadap peserta didik, self-regulated learning (SRL) terhadap prestasi belajar peserta didik, berdasarkan pada model triadic reciprocality dari teori kognitif sosial mendapat dukungan empiris (Bandura, (1986); Brown, 1999, Hergenhahn \& Olson, 2009). Pada model triadic reciprocality dalam teori kognitif sosial yang dielaborasi menjadi model interaksi satu arah. Prestasi belajar sebagai faktor perilaku (behavior) dipengaruhi oleh sikap orangtua terhadap anak dan sikap guru terhadap peserta didik sebagai faktor lingkungan (environment), dan self-regulated learning sebagai foktor personal (person) mendapat dukungan empiris dalam penelitian ini. Secara teoritik, pada model triadic reciprocality 


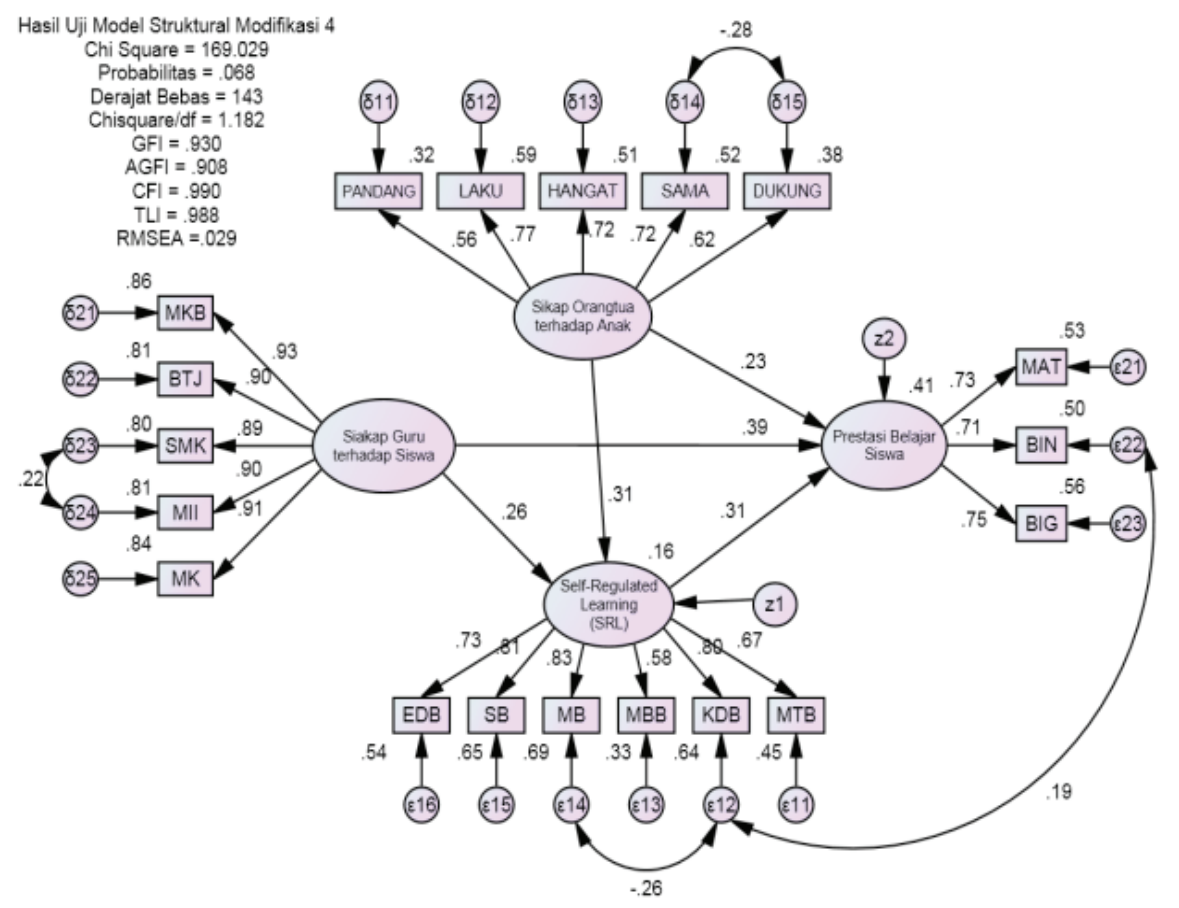

Gambar 2 Hasil Uji Model Persamaan Struktural Modifikasi 4

Tabel 2 Hasil Uji Hipotesis Minor

\begin{tabular}{cccccccc}
\hline Hipotesis & Jalur & Koef. Reg. & Koef. Baku & Salah Baku & CR & p-value & $\begin{array}{c}\text { Hasil } \\
\text { Pengujian }\end{array}$ \\
\hline $\mathrm{H}_{1}$ & $\mathrm{Ot} \rightarrow \mathrm{PB}$ & 2.136 & 0.229 & 0.798 & 2.676 & 0.007 & Diterima \\
$\mathrm{H}^{2}$ & $\mathrm{Gr} \rightarrow \mathrm{PB}$ & 0.567 & 0.394 & 0.109 & 5.184 & 0.000 & Diterima \\
$\mathrm{H}^{3}$ & $\mathrm{Ot} \rightarrow \mathrm{Srl}$ & 0.725 & 0.306 & 0.207 & 3.495 & 0.000 & Diterima \\
$\mathrm{H}^{4}$ & $\mathrm{Gr} \rightarrow \mathrm{Srl}$ & 0.094 & 0.257 & 0.027 & 3.451 & 0.000 & Diterima \\
$\mathrm{H}^{5}$ & $\mathrm{Srl} \rightarrow \mathrm{PB}$ & 1.210 & 0.307 & 0.319 & 3.792 & 0.000 & Diterima \\
$\mathrm{H}_{7}^{6}$ & $\mathrm{Ot} \rightarrow \mathrm{Srl} \rightarrow \mathrm{PB}$ & 0.877 & 0.094 & - & - & - & Diterima \\
\hline
\end{tabular}

\footnotetext{
Keterangan:

$\alpha=0,05$

$\mathrm{Ot}=$ Sikap Orangtua terhadap Anak

$\mathrm{Gr}=$ Sikap Guru terhadap Peserta didik

$\mathrm{Srl}=$ Self-Regulated Learning $(\mathrm{SRL})$

$\mathrm{PB} \quad=$ Prestasi Belajar
}

Tabel 3 Ringkasan Signifikansi Hasil Pengujian Hipotesis

\begin{tabular}{cccccc}
\hline Hipotesis & Jenis Hubungan & Loding Faktor & Koef. Baku & Araf & Keterangan \\
\hline $\mathrm{H}_{1}$ & Kausalitas & 2.136 & 0.229 & Positif & Signifikan \\
$\mathrm{H}_{2}$ & Kausalitas & 0.567 & 0.394 & Positif & Signifikan \\
$\mathrm{H}_{3}$ & Kausalitas & 0.725 & 0.306 & Positif & Signifikan \\
$\mathrm{H}_{4}$ & Kausalitas & 0.094 & 0.257 & Positif & Signifikan \\
$\mathrm{H}_{5}$ & Kausalitas & 1.210 & 0.307 & Positif & Signifikan \\
$\mathrm{H}_{6}$ & Kausalitas & 0.877 & 0.094 & Positif & Signifikan \\
$\mathrm{H}_{7}$ & Kausalitas & 0.114 & 0.079 & Positif & Signifikan \\
\hline
\end{tabular}

yang dielaborasi menjadi model interaksi satu arah. Sikap orangtua terhadap anak dan sikap guru terhadap peserta didik sebagai satu kekuatan eksternal pada faktor lingkungan (environment) dapat berpengaruh langsung terhadap prestasi belajar peserta didik, maupun berpengaruh tidak langsung terhadap prestasi belajar peserta didik.

Temuan empiris model triadic reciprocality hasil elaborasi sikap orangtua terhadap anak berpengaruh langsung terhadap prestasi belajar 
peserta didik ini. Dukungan empiris ini memperkuat penelitian Juang \& Silbereisen (2002); Kordi dan Baharudin(2010); Abar, dkk., (2009); Kusumartiani (2012); Antunes dan Fontaine (2004); dan Mombourquette (2007), yang menyimpulkan sikap orangtua dapat mempengaruhi prestasi belajar secara langsung. Menurut Juang \& Silbereisen (2002) sikap orangtua, seperti; kehangatan, keterlibatan dalam belajar, berdiskusi tentang masalah belajar dan intelektual berpengaruh positif terhadap prestasi belajar anak di sekolah. Penelitian Kordi dan Baharudin (2010) mengungkapkan terdapat hubungan yang kuat antara sikap orangtua dan pola asuh dengan prestasi belajar peserta didik di sekolah. Lebih lanjut Abar, dkk., (2009) juga mengungkapkan bahwa orangtua yang bersikap authoritative (demokrasi) berhubungan positif dengan prestasi belajar dan regulasi diri. Penelitian Kusumartiani (2012), hasil uji hipotesis ini menunjukkan bahwa ada hubungan yang sangat signifikan antara keharmonisan keluarga dengan prestasi akademik pada peserta didik Sekolah Menengah Atas. Keharmonisan keluarga menunjukkan gambaran sikap positif orangtua dalam keluarga berpengaruh terhadap prestasi belajar. Penelitian Antunes dan Fontaine (2004) menemukan bahwa sikap orang yang suportif mempengaruhi prestasi akademik melalui persepsi diri akademik peserta didik. Mombourquette (2007) menemukan bahwa tipe keterlibatan orangtua pada kehidupan remaja peserta didik SMA (adolescent high school students) berhubungan dengan faktorfaktor keterlibatan performansi peserta didik, prestasi akademik, dan sikap terhadap sekolah.

Pengaruh tidak langsung sikap orangtua terhadap anak dengan prestasi belajar peserta didik melalui self-regulated learning (SRL) pada penelitian ini mendapatkan dukungan empiris. Berarti, penelitian ini memperkuat temuan penelitian terdahulu, antar lain penelitian Turner, dkk., (2009); penelitian Strage dan Brandt (Turner, dkk., 2009), dan penelitian Antunes dan Fontaine (2004). Penelitian Turner, dkk., (2009) menguatkan temuan penelitian Strage dan Brandt (Turner, dkk., 2009) menyimpulkan bahwa karakteristik gaya pengasuhan seperti daya dukung dan kehangatan terus memainkan peran penting dalam mempengaruhi kinerja akademik peserta didik setelah memasuki perguruan tinggi.
Studi saat ini menemukan bahwa sikap dan pola asuh authoritative (demokrasi) secara signifikan diprediksi mempengaruhi prestasi belajar, dan tidak ditemukan hubungan gaya pola asuh permisif dan otoriter.

Penelitian Antunes dan Fontaine (2004) menemukan bahwa sikap orang yang suportif memiliki efek positif terhadap persepsi diri akademik peserta didik (children's academic selfperseption). Persepsi diri akademik peserta didik tersebut mempengaruhi performansi akademik peserta didik. Ini berarti sikap orangtua yang suportif mempengaruhi prestasi akademik melalui persepsi diri akademik peserta didik. Temuan empiris model triadic reciprocality hasil elaborasi sikap guru terhadap peserta didik berpengaruh langsung terhadap prestasi belajar peserta didik ini. Temuan empiris pada penelitian ini, memperkuat hasil penelitian Gourneau (2012); Fan (2012); dan membuktikan pendapat Slavin (2000). Penelitian Gourneau (2012) menyimpulkan sikap guru dan tindakan efektif digunakan guru dapat membangun kepercayaan diri yang positif dalam belajar dan prestasi belajar peserta didik. Sikap guru dan tidakan efektif yang dimaksud Gourneau (2012) adalah: (1) kepedulian yang tulus dan kebaikan guru; (2) kesediaan untuk berbagi tanggung jawab yang terlibat dalam kelas; (3) kepekaan yang tulus terhadap keragaman peserta didik; (4) motivasi untuk memberikan pengalaman belajar yang bermakna bagi semua peserta didik; dan (5) antusias untuk merangsang kreativitas peserta didik berpengaruh terhadap prestasi belajar peserta didik.

Penelitian Fan (2012) juga memperkuat hubungan langsung sikap guru terhadap peserta didik dengan prestasi belajar. Fan (2012) menjelaskan bahwa hubungan interpersonal yang baik dan sehat antara guru dan peserta didik merupakan instrumen penentu untuk meningkatkan prestasi belajar peserta didik. Hasil penelitian, dukungan empiris pada penelitian ini memperkuat pendapat Slavin (2000). Menurut Slavin (2000) dalam pembelajaran di kelas guru hendaknya dapat menciptakan suasana belajar yang kondusif. Suasana yang kondusif merupakan gambaran sikap guru dalam pembelajaran di kelas yang memungkinkan peserta didik tidak tegang dalam belajar. Suasana belajar peserta didik yang 
tidak tegang ini akan dapat mendorong peserta didik berprestasi dalam belajar. Pada model triadic reciprocality, yang dibangun dalam penelitian ini pengaruh langsung sikap guru terhadap peserta didik dengan prestasi belajar peserta didik mendapat dukungan empiris. Pengaruh langsung sikap guru terhadap peserta didik dengan prestasi belajar peserta didik merupakan pengaruh langsung yang paling kuat dibandingkan dengan pengaruh langsung sikap orangtua terhadap anak dengan prestasi belajar peserta didik dan pengaruh langsung self-regulated learning (SRL) dengan prestasi belajar peserta didik, maupun pada pengaruh langsung sikap orangtua terhadap anak dengan self-regulated learning (SRL) dan pengaruh langsung sikap guru terhadap peserta didik dengan self-regulated learning (SRL).

Temuan empiris hasil penelitian ini dapat dibenarkan, sebab pengaruh langsung sikap guru terhadap peserta didik sebagi jalur yang paling kuat terhadap prestasi belajar peserta didik, membuktikan bahwa peran guru di sekolah-sekolah amat menentukan baiknya prestasi belajar peserta didik mereka. Pada penelitian sikap guru terhadap peserta didik dipersepsikan dengan baik oleh peserta didik, sikap guru tersebut menunjukkan kepedulian dan kebaikan dalam belajar, sikap berbagi tanggung jawab belajar, guru sensitif menerima keragaman peserta didik dalam belajar, guru dapat meningkatkan instruksi individual, dan guru mampu dengan baik mendorong kreativitas peserta didik dalam belajar berpengaruh signifikan dan positif terhadap prestasi belajar mereka, maka terbukti secara empiris sikap guru terhadap peserta didik berpengaruh langsung terhadap prestasi belajar.

Pada pengaruh tidak langsung hubungan sikap guru terhadap peserta didik terhadap prestasi belajar melalui self-regulated learning (SRL) mendapat dukungan empiris. Hasil penelitian ini mendukung pendapat Slavin (2000) dalam kegiatan pembelajaran guru hendaknya mampu menciptakan kondisi belajar yang kondusif. Kondisi belajar yang kondisif maksudntya adalah kondisi belajar yang penuh dengan kenyamanan, ketenangan, mendorong peserta didik bergairah dalam belajar, serta jauh dari ketegangan dan kecemasan belajar. Sikap ini yang dibutuhkan peserta didik secara psikologis dalam meregulasi dirinya dalam kegiatan pembelajaran untuk mencapai prestasi belajar yang maksimal. Temuan empiris model triadic reciprocality hasil elaborasi model interaksi satu arah, self-regulated learning (SRL) berpengaruh secara langsung terhadap prestasi belajar peserta didik. Temuan empiris penelitian ini, memperkuat hasil penelitian Zimmerman dan Martines-Pons (1990); Cekolin (2001); dan penelitian Alsa (2005).

Penelitian Zimmerman dan Martines-Pons (1990) menyatakan bahwa perilaku aktif dalam proses belajar menghasilkan peningkatan kinerja akademik. Oleh karena itu, peserta didik yang mengunakan Self-regulated learning (SRL) dalam belajar memiliki prestasi belajar yang tinggi. Hasil penelitian mereka juga menemukan bahwa peserta didik yang memiliki prestasi akademik tinggi, menggunakan 13 dari 14 perilaku regulasi diri. Temuan empiris penelitian ini mendukung penelitian Cekolin (2001), peserta didik yang menggikuti pelatihan self-regulated learning (pelatihan strategi regulasi diri dalam belajar) mendapatkan prestasi belajar yang lebih tinggi daripada kelompok yang tidak mengikuti pelatihan. Penelitian Alsa (2005) menemukan ada korelasi positif yang sangat signifikan antara belajar berdasar regulasi diri (self-regulated learning) dengan prestasi belajar matematika pada pelajar. Temuan empiris model triadic reciprocality hasil elaborasi model interaksi satu arah, sikap orangtua terhadap anak dan sikap guru terhadap peserta didik berpengaruh secara langsung terhadap self-regulated learning (SRL). Temuan empiris penelitian ini, memperkuat hasil penelitian Abar, dkk., (2009) dan Slavin (2000).

Penelitian Abar, dkk., (2009) menemukan orangtua yang bersikap authoritative (demokrasi) berhubungan positif dengan prestasi belajar dan regulasi diri (self-regulated learning) dan beberapa variabellainnya.Lebihlanjut, menurutSlavin(2000) dalam proses pembelajaran hendaknya guru dapat menciptkanan kondisi belajar yang kondusif, yaitu kondisi belajar yang menyenangkan, tidak tegang, dan suasana yang nyaman dalam pembelajaran. Sikap guru yang seperti ini berpengaruh terhadap perilaku, motivasi, dan prestasi belajar peserta didik. Maka dapat disimpulkan sikap guru berpengaruh terhadap perilaku peserta didik dan motivasi peserta didik dalam belajar, karena 
perilaku dan motivasi merupakan komponen dalam self-regulated learning (SRL), jadi Sikap guru berpengaruh terhadap self-regulated learning (SRL).

Pada model triadic reciprocality,yang dibangun dalam penelitian ini pengaruh langsung sikap orangtua terhadap anak dan sikap guru terhadap peserta didik dengan self-regulated learning (SRL) mendapat dukungan empiris. Pengaruh langsung sikap orangtua terhadap anak merupakan jalur pengaruh langsung yang paling kuat terhadap self-regulated learning (SRL) dibandingkan dengan pengaruh langsung sikap guru terhadap peserta didik dengan self-regulated learning (SRL). Temuan empiris penelitian ini dapat dibenarkan, sebab anak lebih banyak waktu berinteraksinya lebih banyak dengan orangtua dibanding dengan guru. Sikap orangtua terhadap anak terutama pada perlakuan terhadap anak untuk berprestasi dalam belajar, membangun kehangatan belajar, dan membangun kebersamaan dalam belajar dipersepsikan baik oleh anak, sehingga sikap orangtua ini terbukti secara empiris berpengaruh langsung terhadap self-regulated learning (SRL). Hasil penelitian ini memperkuat penelitian Abar, dkk. (2009) bahwa orangtua yang bersikap authoritative (demokrasi) berhubungan positif dengan regulasi diri (self-regulated learning).

\section{SIMPULAN DAN SARAN}

Hipotesis yang diajukan pada penelitian ini, terdapat hubungan kausal antara sikap orangtua terhadap anak, sikap guru terhadap peserta didik, self-regulated learning (SRL) dengan prestasi belajar peserta didik telah terbukti layak/fit dan mendapat dukungan empiris. Hasil pengujian hipotesis ini membuktikan model teoritik yang dibangun, terdapat pengaruh sikap orangtua terhadap anak, sikap guru terhadap peserta didik, dan self-regulated learning (SRL) terhadap prestasi belajar peserta didik, menjadi teori: (1) sikap orangtua terhadap anak mempengaruhi selfregulated learning (SRL) dan prestasi belajar peserta didik; (2) sikap guru terhadap peserta didik mempengaruhi prestasi belajar peserta didik, dan self-regulated learning (SRL); dan (3) selfregulated learning (SRL) mempengaruhi prestasi belajar peserta didik.
Saran penelitian ini: (1) guru agar bersikap kondusif, peduli, bertanggung jawab, sensitif, dan mendorong kreativitas peserta didik, menggali dan mengenalkan self-regulated learning dengan 6 faktor pembentuknya dan melakukan pelatihan selfregulated learning, melakukan penelitian tindakan kelas (PTK) berkaitan dengan faktor-faktor yang mempengaruhi prestasi belajar; (2) orangtua agar berpandangan positif terhadaap anak, berdiskusi dan menggali potensi diri anak terutama yang berkaitan dengan self-regulated learning; dan (3) peneliti selanjutnya untuk melakukan penelitian tentang variabel pada penelitian ini di tingkat pendidikan yang lainnya.

\section{DAFTAR RUJUKAN}

Abar, B., Carter, K., L., \& Winsler, A. 2009. The Effects of Maternal Parenting Style and Religious Commitment on Self-Regulation, Academic Achievement, and Risk Behavior among African-American Parochial College Students . Journal of Adolescence, 32, 259273.

Atmoko, A. 2008. Model Tindakan Guru Menanggapi Perilaku Emosional Siswa dalam Pembelajaran Sekolah Dasar di Kota Malang. Disertasi tidak diterbitkan. Malang: Program Pascasarjana Universitas Negeri Malang.

Bandura, A. 1977. Social Learning Theory. New Jersey: Prentice Hall, Inc.

Bandura, A. 1986. Social Fondations of Thought and Action: A Social Cognitive Theory. New Jersey: Prentice-Hall, Inc. Engglewood Cliffs.

Battist, V. 1999. Toward A More Adequate Assessment of Moral Development. Developmental Studies Center, (Online), (http://www.devstu.org/articles/AME99.pdf), diakses 10 Maret 2012.

Belen, S. 2003. Apa, Mengapa, dan Bagaimana Kurikulum Berbasis Kompetensi. Makalah disampaikan dalam Seminar Peningkatan Strategi Guru Menghadapi Kurikulum Berbasis Kompetensi, Yayasan Abdi Siswa, Jakarta.

Bogle, K. 2000. Effect of Type of Student and Gender on the Attribution of Cheating. Proceedings of the Oklahoma Academy of Science, Volume 80, p. 91-97. (Online), 
(http://digital.library.okstate.edu/oas/oas pdf/v80/p91_97.pdf), diakses 5 Maret 2012.

Brown, K. M. 1999. Social Cognitive Theory, (Online), (http://www.med.usf.edu/ Cognitive_ Theory_Overview.html), diakses 15 Oktober 2012.

Daruma, A. R. 1997. Hubungan antara Taraf Inteligensi, Kepercayaan Diri, dan Pendidikan Orang Tua dengan Kreativitas Anak. Tesis tidak diterbitkan. Yogyakarta: Universitas Gadjah Mada.

Fan, F.A. 2012. Teacher: Students' Interpersonal Relationships and Students' Academic Achievements in Social Studies. Journal: Teachers and Teaching, 18(4), 483-490.

Gall, M. D., Gall, J. P., \& Borg, W. R. 2003. Educational Reseach. Boston: Allyn and Bacon.

Gerungan, W. A. 2008. Psikologi Sosial. Jakarta: PT Eresco.

Gourneau, B. 2012. Five Attitudes of Effective Teachers: Implications for Teacher Training. Journal of Human Behavior in the Social Environment, 19(4), 113-123.

Hair, J. F. Jr. Black, W. C., Babin, B. J., Anderson, R. E., \& Tatham, R. L. 1998. Multivariate Data Analysis. $5^{\text {th }}$ ed. New Jersey: Prentice Hall.

Hair, J. F. Jr. Black, W. C., Babin, B. J., Anderson, R. E., \& Tatham, R. L. 2006. Multivariate Data Analysis. $6^{\text {th }}$ ed. New Jersey: Prentice Hall.

Hair, J. F. Jr. Black, W. C., Babin, B. J., Anderson, R. E., \& Tatham, R. L. 2010. Multivariate Data Analysis. $7^{\text {th }}$ ed. New Jersey: Prentice Hall.

Hemisevis, H. \& Hodzic, S. 2011. Teachers' Attitudes towards Inclusion of Students with Intellectual Disability in Bosnia and Herzegovina. International Journal of Inclusive Education, 15(7), 699-710.

Hergenhahn, B. R., \& Olson, M. H. 2009. Theories of Learning. Jakarta: Fajat Interpratama Offset.

Hetherington, J., Parke, M. D., Martin, C. A., \& Colbert, C. A. 2007. Parenting: A life Span Perspective. New York: McGraw-Hill Companies.
IEA. 2011. International Association for the Evaluation Educational Achievement, (Online), (http://www.iea.nl/about_us.html), diakses 8 Oktober 2012.

Ismayati, E. 2009. Pengembangan Model pengajaran Conductive untuk Meningkatkan Kemampuan Siswa Berpikir Kritis dan Bekerja Kolaboratif pada Pembelajaran Fisika di SMK. Disertasi tidak diterbitkan. Malang: Program Pascasarjana Universitas Negeri Malang.

Kline, R. B. 2011. Principles and Practice of Structural Equation Modeling. New York, London: The Guilford Press.

Krech, C., Crutchfield, R., \& Ballachey, E.L., 2002. Individual In Society. Tokyo: McGrawHill. International Company.

Kusumartiani, A. 2012. The Relationship between the Harmonious of Family with Students Academic Achievement of Senior High School. E-Journal Psychologi, (Online), (http://hdl.handle.net/123456789/1130), diakses 17 Maret 2013.

Lifshitz, H., Glaubman, R., \& Issawi, R. 2004. Attitudes towards Inclusion: The Case of Israeli and Palestinian Regular and Special Education Teachers. European Journal of Special Needs Education, 19(2), 171-190.

Richards, A., French, C.C., and Randall, F. 2006. Anxiety the Use of Strategies in the Performance of a Sentence-Picture Verification Task. Journal of Abnormal Psychology, 105(1), 132-136.

Rittman, A. L. 1996. Academic Dishonesty among College Students, (Online), (http://www. mwsc.edu/psychology/research/psy302/ fall96/andi_rittman.html), diakses 5 Maret 2012.

Slavin, R. E. 2000. Educational Psychology: Theory and Practices. New York: Allyn \& Bocan.

Thorpe, M. F., Pittenger, D. J., \& Reed, B. D. 1999. Cheating the Researcher: A Study of the Relation between Personality Measures and Self-Reported Cheating. College Student Journal, 33, 49-59.

TIMSS. 2011. Trends in International Mathematics and Science Study, (Online), (http://www.iea. nl/timss_2011.html), diakses 8 Oktober 2012. 
Tuckman, B. W. 1978. Conducting Educationa in Research. New York: Harcourt Brace Jovanovich, Publishhers.

Turner, E., A., Chandler, M., \& Heffer, R., W. 2009. The Influence of Parenting Styles, Achievement Motivation, and Self-Efficacy on Academic Performance in College Students. Journal of College Student Development, 50(3), 337-346.

Turrens, J. F., Staik, I. M., Gilbert, D. K., Small, W. C. \& Burling, J. W. 2002. Undergraduate Academic Cheating as a Risk Factor for Future Professional Misconduct. Proceeding of the First ORI Research Conference on Research Integrity, Dept. of Health and Human Service, pp. 49-52. (Online), (http:// ori.dhhs.gov/multimedia/acrobat/papers/ turrens.pdf), diakses 21 Mei 2012.

Vahedi, Shahram, Mostafafi, Faride, Mortazanajad, Habibeh. 2009. Self-Regulation and Dimensions of Parenting Styles Predict Psychological Procrastination of Undergraduate Students. Iranian Journal of Psychiatry, 4(4), 12-19.
Walgito, B. 1994. Psikologi Sosial Suatu Pengantar. Yogyakarta: Andi Offset.

Winarto, Y. T., Subardiyanto, T., \& Choesin, E. M. 2004. Karya Tulis Ilmiah Sosial. Jakarta: Yayasan Obor Indonesia.

Winkel, W. S. 2003. Psikologi Pendidikan dan Evaluasi Belajar. Jakarta: Gramedia.

Zimmerman, B. J. \& Martinez-Pons, M. 1990. Student Differences in Self-Regulated Learning: Relating Grade, Sex, and Giftedness to Self-Efficacy and Strategy Use. Journal of Educational Psychology, 82, 51-59.

Zumbrunn, S., Tadlock, J., \& Roberts, E.D. 2011. Encouraging Self-Regulated Learning in the Classroom: A Review of the Literature. Virginia: Metropolitan Educational Research Consortium (MERC), Virginia Commonwealth University. 